\title{
Gamma-Secretase Subunit PEN-2
}

National Cancer Institute

\section{Source}

National Cancer Institute. Gamma-Secretase Subunit PEN-2. NCI Thesaurus. Code C104809.

Gamma-secretase subunit PEN-2 (101 aa, $12 \mathrm{kDa}$ ) is encoded by the human PSENEN gene. This protein plays a role in Notch protein cleavage and signal transduction. 